\title{
ЗАРУБІЖНИЙ ТА ВІТЧИЗНЯНИЙ ДОСВІД ФОРМУВАННЯ СТРАТЕГІЇ РОЗВИТКУ ЗАЛІЗНИЧНОГО ТРАНСПОРТУ В УМОВАХ ОРГАНІЗАЦІЇ ШВИДКІСНОГО РУХУ
}

\author{
Дейнека О.Г., д.е.н., професор, \\ Бузін П.А., магістр програми ТЕМПУС (УкрДУЗТ)
}

\begin{abstract}
Більшість залізниць світу на початку століття зіткнулися з тим, щуо темпи поглиблення проблем, щзо стоять перед залізничним транспортом, стали випереджати темпи оновлення та розвитку галузі. Швидке накопичення внутрішньо системних порушень загрожувало лавиноподібним наростанням різних дефектів (технологічних збоїв, аварій, зниженням якості послуг, щуо надаються), ие ставало серйозною перешкодою для збереження гарантованого рівня надійності, безпеки та ефрективності функиіонування залізниць. Забезпечення конкуренто спроможності залізничного транспорту базується на необхідності організації швидкісного $i$ високошвидкісного руху.

Криза залізничного транспорту у всьому світі була пов'язана також із зміною технологічної парадигми і проблемами, щзо виникли через не конкурентоспроможність залізниць в порівнянні з новими видами транспорту через багаторазове зростання витрат для підтримки й відновлення інфраструктури залізниць.

У більшості зарубіжних країн першим кроком для вирішення ичих проблем стало проведення реформ залізничного транспорту, тобто розпочався процес реформування.

Ключові слова: криза, залізничний транспорт, галузь, послуги, конкурентоспроможність, технологія, витрати, формування, досвід.

\section{ЗАРУБЕЖНЫЙ И ОТЕЧЕСТВЕННЫЙ ОПЫТ ФОРМИРОВАНИЯ СТРАТЕГИИ РАЗВИТИЯ ЖЕЛЕЗНОДОРОЖНОГО ТРАНСПОРТА В УСЛОВИЯХ ОРГАНИЗАЦИИ СКОРОСТНОГО ДВИЖЕНИЯ}

\author{
Дейнека А.Г., о.э.н., профессор, \\ Бузин П.А., магистр программы ТЕМПУС (УкрГУЖТ)
}

Большинство железных дорог мира в начале века столкнулись с тем, что темпы углубления проблем, стоящих перед железнодорожным транспортом, стали опережать темпь обновления и развития отрасли. Быстрое накопление внутри системных нарушений грозило лавинообразным нарастанием различных дефектов (технологических сбоев, аварий, снижением качества предоставляемых услуг), это становилось серьезным препятствием для сохранения гарантированного уровня надежности, безопасности и эффективности функиионирования железных дорог. Обеспечение конкурентоспособности способности железнодорожного транспорта базируется на необходимости организации скоростного и высокоскоростного движения.

Кризис железнодорожного транспорта во всем мире была связана также с изменением технологической парадигмы и проблемами, возникшими из-за не конкурентоспособность железных дорог по сравнению с новыми видами транспорта через многократный рост расходов на поддержание и восстановление инфраструктуры железных дорог.

(C) Дейнека О.Г.,

Вісник економіки транспорту і промисловості № 63, 2018

Бузін П.А. 
В большинстве зарубежных стран первым шагом для решения этих проблем стало проведение реформ железнодорожного транспорта, то есть начался процесс реформирования.

Ключевые слова: кризис, жселезнодорожнный транспорт, отрасль, услуги, конкурентоспособность, технология, расходы, формирование, опыт.

\title{
FOREIGN AND DOMESTIC EXPERIENCE OF FORMING THE RAILWAY DEVELOPMENT STRATEGY IN THE CONDITIONS OF THE ORGANIZATION OF SPEED MOVEMENT
}

\author{
Deineka O.G., Doctor of Economic Sciences, Professor, \\ Buzin P.A., Master of program TEMPUS (USURT)
}

Most of the railways in the world in the beginning of the century faced with the fact that the pace of deepening the problems facing the railroad, began to outstrip the pace of renovation and development of the industry. Rapid accumulation of internal systemic violations threatened an avalanche-like increase in various defects (technological failures, accidents, reduced quality of services provided), this became a serious obstacle to maintaining a guaranteed level of reliability, safety and efficiency of the railways. The competitiveness of rail transport is based on the need to organize high-speed and high-speed traffic.

The global railway crisis has also been linked to a change in technological paradigm and the problems that have arisen due to the lack of competitiveness of railways compared to new modes of transport, due to the multiple cost increases for rail infrastructure maintenance and restoration.

In most foreign countries, the first step towards solving these problems has been the implementation of rail transport reforms, that is, the process of reform has begun.

Reformation is a process of changing the directions of activity that is associated with the emergence of a market economy and a change in the socio-economic conditions of functioning. It includes the reform of property relations (reorganization, corporatization, restructuring and privatization) and adaptation of goals, strategies, policies and organizational structure of management to new conditions of functioning in a market economy.

Implementation of the reform process can not be without a reasonable and recorded in the form of a separate document development strategy. That is, the initial stage of the reform process is the establishment of a mission, the definition of the main goals and directions of development.

In order to implement the reform process in the railway transport, in particular, the countries of the European Union also applied the following development strategies: reorganization, corporatization, restructuring and privatization, as well as the strategy of organization of high-speed traffic. In this regard, a standardized set of management tools was developed. This choice includes the methods of separating the functions of state regulation and management of economic activity, the allocation of natural monopoly and competitive sectors, the regulation of activities that are not natural monopoly, the procedures for transition from a monopoly industry to a competitive and many others that with greater or less successfully used in the last 20-30 years.

Key words: crisis, railway transport, industry, services, competitiveness, technology, costs, formation, experience. 
Постановка проблеми. Більшість залізниць світу на початку століття зіткнулися 3 тим, що темпи поглиблення проблем, що стоять перед залізничним транспортом, стали випереджати темпи оновлення та розвитку галузі. Швидке накопичення внутрішньо системних порушень загрожувало лавиноподібним наростанням різних дефектів (технологічних збоїв, аварій, зниженням якості послуг, що надаються), це ставало серйозною перешкодою для збереження гарантованого рівня надійності, безпеки та ефективності функціонування залізниць. Забезпечення конкуренто спроможності залізничного транспорту базується на необхідності організації швидкісного i високошвидкісного руху.

Криза залізничного транспорту у всьому світі була пов'язана також із зміною технологічної парадигми i проблемами, що виникли через не конкурентоспроможність залізниць в порівнянні 3 новими видами транспорту через багаторазове зростання витрат для підтримки й відновлення інфраструктури залізниць.

У більшості зарубіжних країн першим кроком для вирішення цих проблем стало проведення реформ залізничного транспорту, тобто розпочався процес реформування.

Реформування - це процес зміни напрямків діяльності, який пов'язаний зі становленням ринкової економіки та зміною соціально-економічних умов функціонування. Він включає реформування відносин власності (реорганізацію, корпоратизацію, реструктуризацію та приватизацію) та адаптацію цілей, стратегій, політики i організаційної структури управління до нових умов функціонування в умовах ринкової економіки.

Здійснення процесу реформування неможливо без обгрунтованої та зафіксованої у виді окремого документу стратегії розвитку. Тобто, початковим етапом процесу реформування $\epsilon$ встановлення місії, визначення основних цілей та напрямків розвитку.

Для реалізації процесу

реформування на залізничному транспорті, зокрема, країни Європейського союзу також застосовували наступні стратегії розвитку:реорганізацію, корпоратизацію, реструктуризацію та приватизацію ,a також стратегію організації швидкісного руху. У зв'язку з цим було розроблено стандартизований набір інструментів управління. Цей вибір, включає в себе методи розділення функцій державного регулювання та управління господарською діяльністю, виділення природно-монопольних i конкурентних секторів, регулювання видів діяльності, які не $\epsilon$ природно-монопольними, процедури переходу від монопольного стану галузі до конкурентного і багато інших, які з більшим чи меншим успіхом використовуються протягом останніх 2030 років.

Потреба у реформуванні підприємств залізничного транспорту обумовила розроблення п'яти загальних стратегічних варіантів реорганізації залізниць.

До теоретичних варіантів реорганізації залізниць відносяться:

- унітарна залізниця;

- орієнтація залізниць на конкретні види обслуговування;

- конкурентний підхід;

- «оптовий» підхід;

- «стягнення плати

3a

використання» .

Рішення про перевагу якогось варіанта $\epsilon$ питанням вибору між ефективністю виробництва і ефективністю задоволення потреб ринку. Рейтинг варіанта унітарної залізниці високий 3 точки зору технічної ефективності, оскільки експлуатаційні конфлікти вирішуються директивно, але невисокий 3 точки зору маркетингу. Варіант орієнтації на конкретні види обслуговування характеризується кращою спроможністю реагувати на ринкові зміни та аналізувати 
доходи i витрати за видами обслуговування, але відрізняється більш високою вірогідністю експлуатаційних конфліктів i витрат 3 реорганізації у декілька разів. Варіант конкурентного підходу вводить конкуренцію усередині галузі на окремих ринках при збереженні єдиного управління більшістю залізничних операцій. Але такий варіант часто $є$ процесом еволюційним. Варіант «оптового» підходу передбачає високу компетенцію служб маркетингу, але функції експлуатації повинні залишатися в єдиних руках. Варіант «стягнення плати за використання» ближчий за інших до теоретичної моделі ефективного маркетингу, але відрізняється високою вірогідністю експлуатаційних конфліктів і витрат. Цей варіант потребує значних зусиль в управлінні 3 боку державних структур .

У реальних умовах складні поєднання методів експлуатації, видів обслуговування і особливостей географічних зон, які характеризують розвинуті залізничні системи, можуть вимагати складної комбінації можливих варіантів реорганізації. Найбільш поширеними варіантами реорганізації системи управління в країнах світу стали:

- вертикальне або горизонтальне розділення. При такому підході, власність на інфраструктуру відокремлюється від власності на перевезення. Переважна форма конкуренції при такому підході - це конкуренція між операторамиперевізниками. Ці компанії у свою чергу можуть бути розділені горизонтально, і конкуренція на різних сегментах може бути дозволена чи ні. Найбільш чисті приклади такого роду поділу були здійснені у Великобританії та Швеції.

$$
\text { - вертикальна інтеграція }
$$

регульованим доступом. У цьому випадку базовий (cumbent) оператор залізниць залишається вертикально інтегрованим (хоча може мати місце часткове горизонтальне розділення). При цьому конкуруючі отримують оператори-перевізники право доступу до інфраструктури базового оператора на регульованих умовах. Основна форма конкуренції при цьому підході конкуренція між компаніями перевізниками, які не володіють доступом до інфраструктури, а також між ними та інтегрованим базовим оператором;

$$
\text { - вертикальна інтеграція }
$$
горизонтальним поділом). У цьому підході базовий (incumbent) інтегрований залізничний оператор поділяється на кілька компаній, що володіють певним набором маршрутів (route-baaed). У цьому випадку головні форми конкуренції - паралельна конкуренція (за наявності паралельних шляхів, що належать різним компаніям) i конкуренція вибору вантажовідправником пункту доставки (ринку збуту його товару - end-market copetition) разом 3 вибором перевізника (source competition). Крім того, кожен інтегрований оператор може встановити угоди 3 іншими операторами про взаємне надання своїх шляхів для руху поїздів конкурента;

$\begin{array}{cccc}\text { - } & \text { об'єднана } & \text { або } & \text { загальна } \\ \text { власність } & \text { у } & \text { цьому } & \text { варіанті }\end{array}$ інфраструктура природної монополії (або частина іii) знаходиться у спільній власності компаній - операторів поїздів. На практиці такий підхід до цих пір використовувався лише стосовно деяких обслуговуючих структур (таких як центральний вокзал у Мехіко або деякі ключові ділянки колії).

Розглянуті підходи не $є$ несумісними. Можливо, наприклад, відділення інфраструктури від вантажних перевезень при збереженні інтеграції 3 пасажирськими послугами (як це має місце в Японіï).

Особливої уваги набуває проблема реорганізації залізниць у зв'язку 3 визначеним напрямком їх розвитку через збільшення швидкості перш за все пасажирських сполучень. Необхідність грунтивного дослідження саме цього обумовила вибір до написання цієї статті.

Аналіз останніх досліджень та публікацій. Питання, де розглянуто проблеми зарубіжного та вітчизняного 
досвіду формування стратегії, розвитку залізничного транспорту в умовах організації швидкісного руху опублікованого у чисельних статтях вчених Укр. ДУЗТ проф. Дикань В.Л., [1]; проф. Позднякова Л.О., доц. Котик В.О. [2]; та Дніпропетровського національного університету залізничного транспорту проф. Бараш Ю.С., [3]; Доречно також відзначити наявність періодичного видань журналів Залізничний транспорт України та Економіки України. Проблеми стратегії залізниць ще не достатньо глибоко пов'язаний 3 організацією швидкісного i високошвидкісного руху.

Мета статі орієнтується на вивченні i аналізі досвіду формування стратегії розвитку залізничного транспорту, що безпосередньо впливає на забезпечення конкурентоспроможності залізниць.
Виклад основного матеріалу. Практичний досвід роботи залізниць світу показав, що на базі відомих моделей кожною країною розроблялися власні моделі, котрі враховували національні умови та реалізовували поставлені завдання. Так, у світовій практиці з'явилися наступні моделі:

- американська модель - наявність декількох вертикально інтегрованих компаній, які конкурують на одних i тих же напрямках;

- європейська модель - єдина інфраструктура відокремлена від перевізної діяльності. Перевізники конкурують або «на коліях», або за право доступу до інфраструктури;

- унітарна модель - залізниці $\epsilon$ державною монополією.

Моделі реформування залізниць розвинутих країн світу наведені у табл.1.

Таблиия 1

Моделі реформування залізнииь розвинутих країн світу

\begin{tabular}{|c|c|c|c|c|}
\hline \multirow[t]{2}{*}{ Модель } & \multirow{2}{*}{$\begin{array}{l}\text { Країни-основні } \\
\text { представники }\end{array}$} & \multirow{2}{*}{$\begin{array}{l}\text { Варіанти } \\
\text { реорганізації }\end{array}$} & \multicolumn{2}{|c|}{$\begin{array}{l}\text { Форма власності на } \\
\text { перевезення }\end{array}$} \\
\hline & & & вантажів & пасажирів \\
\hline $\begin{array}{l}\text { Американська } \\
\text { модель }\end{array}$ & США & \begin{tabular}{|l} 
Вертикальна \\
інтеграція \\
регульованим \\
доступом \\
\end{tabular} & $3 \mid \begin{array}{l}\text { Приватні } \\
\text { оператори }\end{array}$ & $\begin{array}{l}\text { Державні } \\
\text { компанії }\end{array}$ \\
\hline \multirow{3}{*}{$\begin{array}{l}\text { Європейська } \\
\text { модель }\end{array}$} & $\begin{array}{l}\text { Німеччина, Італія, } \\
\text { Австрія }\end{array}$ & \begin{tabular}{|l} 
Вертикальна \\
інтеграція \\
горизонтальним \\
розділенням \\
\end{tabular} & \multirow{2}{*}{$\begin{array}{l}\text { Приватні та } \\
\text { державні } \\
\text { оператори }\end{array}$} & \multirow{2}{*}{$\begin{array}{l}\text { Державні } \\
\text { компанії } \\
\text { далеких } \\
\text { сполученнях }\end{array}$} \\
\hline & Іспанія & $\begin{array}{l}\text { Горизонтальне } \\
\text { розділення }\end{array}$ & & \\
\hline & Великобританія & $\begin{array}{l}\begin{array}{l}\text { Горизонтальне } \\
\text { розділення }\end{array} \\
\end{array}$ & \begin{tabular}{|l|} 
Приватні \\
оператори \\
\end{tabular} & \begin{tabular}{|l|} 
Приватні \\
оператори \\
\end{tabular} \\
\hline Унітарна модель & $\begin{array}{l}\text { Росія,Україна, } \\
\text { країни Африки та } \\
\text { Азії }\end{array}$ & & $\begin{array}{l}\text { Державні } \\
\text { компанії }\end{array}$ & $\begin{array}{l}\text { Державні } \\
\text { компанії }\end{array}$ \\
\hline
\end{tabular}

У відповідності до обраного курсу України на інтеграцію в СС реформування залізничного транспорту має бути спрямоване на майбутню інтеграцію залізниць України в загальноєвропейську залізничну мережу. Це - обумовлює подальший вибір європейського варіанту реформування залізничного транспорту України. 
У зв'язку з цим правовою основою реформування залізничної галузі України $\epsilon$ свропейське та національне законодавство. Європейське законодавство по залізничному транспорту містить пакет директив $€ \mathrm{C}$, вимоги яких $\epsilon$ обов'язковими для виконання країнамикандидатами на вступ до ЄС [5]:

директива Свропейського парламенту I Ради 2001/12/СС від 26 лютого 2001 року, яка доповнює та змінює Директиву 91/440/СС по розвитку залізниць;

-директива 2001/13/€C

Європейського парламенту та Ради від 26 лютого 2001 року, яка доповнює та змінюе Директиву 95/18/€С Ради по ліцензуванню залізничних підприємств; -директива 2001/14/EC

Європейського парламенту та Ради від 26 лютого 2001 року про розподіл пропускної спроможності залізничної інфраструктури, стягування плати за користування залізничною інфраструктурою та сертифікації на відповідність вимогам безпеки.

Основні положення Директиви Європейського парламенту I Ради 2001/12/СС від 26 лютого 2001 року (яка доповнює та змінює Директиву 91/440/СС по розвитку залізниць) вимагають від залізничних адміністрацій забезпечення справедливого і рівноправного доступу до залізничної інфраструктури всім ліцензованим залізничним підприємствам, виконуючих вимоги безпеки. При цьому інституціональне відокремлення інфраструктури від експлуатаційної діяльності $є$ необов'язковим, але обов'язково мають бути розділені рахунки доходів та витрат й бухгалтерських балансів, а витрати по утриманню та експлуатації інфраструктури відокремлені від витрат по перевезеннях, витрати по пасажирських перевезеннях відокремлені від витрат по вантажних перевезеннях.

\section{Директива 2001/13/€C}

Європейського парламенту та Ради від 26 лютого 2001 року, яка доповнює та змінює
Директиву 95/18/ЄC, надає умови ліцензування 3 метою забезпечення дії права доступу до залізничної інфраструктури залізничних підприємств.

$$
\text { Директива }
$$
2001/14/CC

Свропейського парламенту та Ради від 26 лютого 2001 року формує принципи розподілу пропускної спроможності залізничної інфраструктури, забезпечення оптимальних режимів використання залізничної інфраструктури стягування плати за користування залізничною інфраструктурою та сертифікації рухомого складу i iнших основних виробничих фондів на відповідність вимогам безпеки.

Незважаючи на різноманітність підходів до реформування залізниць в країнах $\mathrm{CC}$, основні етапи реформ загалом співпадають (рис.1).

Це підтверджується новим законом про акціонування залізничного транспорту України від 23.02.2012 р. [6], який також передбачає реалізацію реформування у три етапи:

1 етап (2012-2013 рр.) -створення єдиної державної акціонерна компанія 3 розділенням функцій між державою та акціонерною залізничною компанією;

2 етап (2013-2015 рр.) - створення вертикально-інтегровані виробничотехнологічні системи залізничного транспорту, структуровані за видами діяльності.

На етапі стратегії реструктуризації на державу будуть покладені такі функції:

- управління та фінансування розвитку транспортної інфраструктури;

- вирішення питання про заборгованість залізниць перед державою;

- забезпечення рівного доступу незалежних компаній - операторів до залізничної інфраструктури;

- встановлення пільгових тарифів та компенсування залізницям можливих збитків від їх застосування;

- сприяння створенню самостійних залізничних компаній - операторів 3 метою розвитку внутрішньої i міжгалузевої конкуренції. 


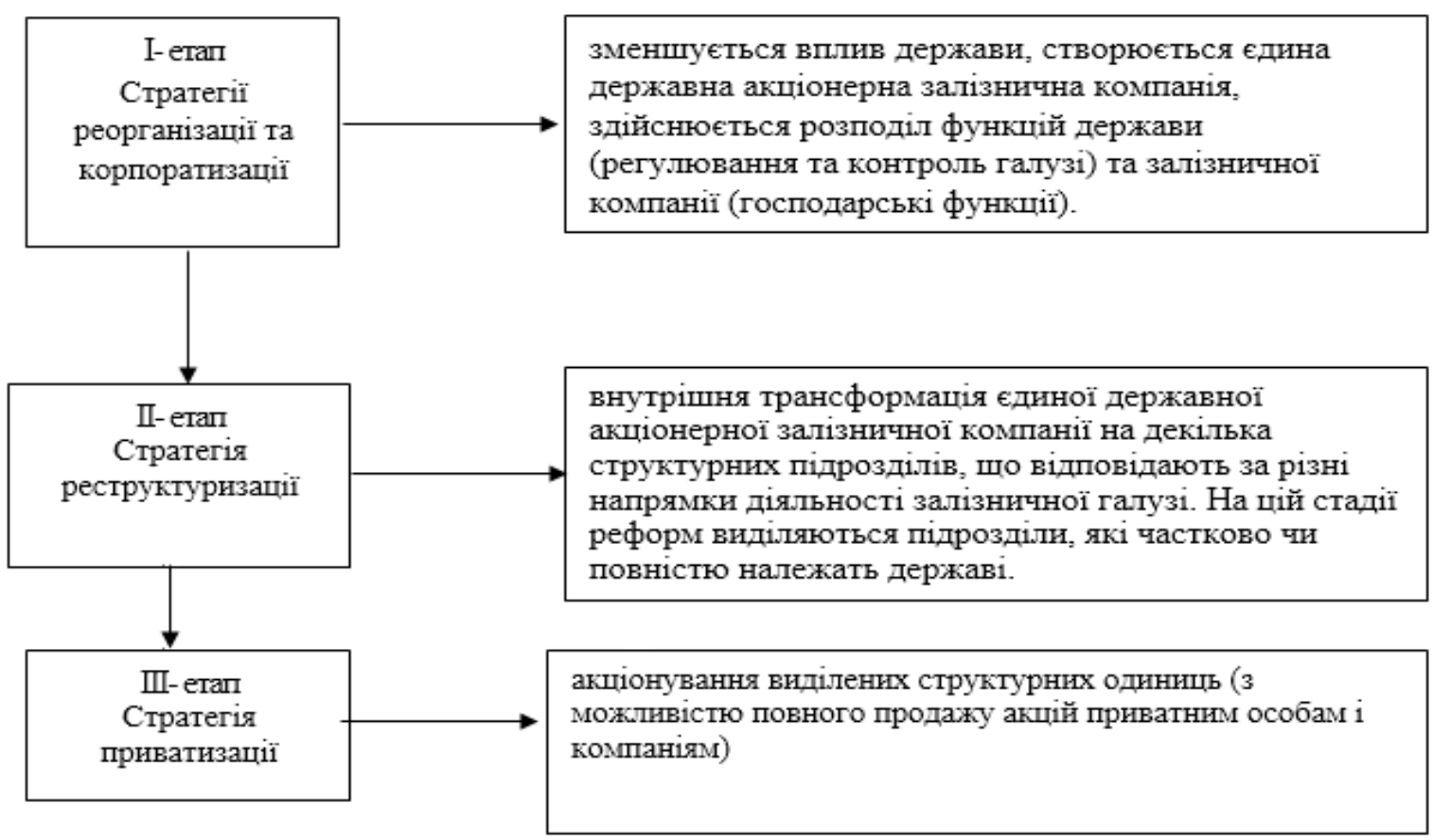

Рис. 1 Основні етапи реформування залізниць в країнах $Є C$

Залізниці 3 свого боку при реалізації даної стратегії будуть виконувати такі функції:

- управління рухом і експлуатацією;

- організація пасажирів, вантажів, пошти;

- утримання i

перевезення інфраструктури;

- здійснення допоміжної діяльності.

3 етап (2016-2019 рр.) ліквідація перехресного субсидування пасажирських перевезень за рахунок вантажних i створення господарське товариство у сфері пасажирських перевезень.

На етапі приватизації здійснюється переведення діяльності залізничної галузі на комерційні засади, а саме:

відмова від адміністративних

та перехід до економічних методів управління

на основі прибутковості

перевезень;

- використання маркетингових

принципів у взаємодії з користувачами послуг та підвищення на цій базі прибутковості і конкурентної привабливості транспортних послуг.
Порівнюючи основні етапи реформування залізничної галузі, які відбулися в країнах $€ C$ та зараз реалізуються в Україні видно, що вони мають схожу структуру i націлені на однаковий результат, що підтверджується інтеграційним курсом нашої держави у світову транспортну систему.

Як показує досвід роботи закордонних залізниць, початковим етапом процесу реформування $\epsilon$ визначення відповідних стратегічних напрямків та пріоритетів.

Ураховуючи інтеграційний курс нашої держави необхідно проаналізувати сучасні пріоритети стратегічного розвитку Європейського залізничного транспорту, основними 3 яких $є$ створення системи комплексного транспортного обслуговування 3 використанням механізмів маркетингу та інтеграція у діяльність міжнародних логістичних ланцюгів, які передбачають:

- підпорядкування технології перевізного процесу вимогам маркетингу та логістики, що передбачає своєчасну доставку вантажів, забезпечення їх 
збереження, високу швидкість, швидку реакцію на вимоги клієнтури, можливість доставки вантажу за принципом «від дверей до дверей», гнучкі тарифи;

- розробка системи оцінки якості обслуговування (графіки, строки доставки, інформаційне забезпечення, надійність транспортних коштів);

- розвиток міжнародного транзиту, який $\epsilon$ складовою сучасних міжнародних економічних відносин між різними країнами;

створення

транспортних коридорів, з'єднуючих важливі пункти відправлення та призначення, по яким слідують пріоритетні вантажні поїзди 3

- встановленим часом виконання операцій та фіксованим прибуттям до пунктів призначення;

- подальший

розвиток

відправницької маршрутизації, яка охоплює основний обсяг масових вантажів, введення одно- та двохгрупових поїздів підвищеної транзитності; скорочення переробки вагонопотоків на шляху прямування;

- впровадження

системи

перевезень (типу «Карго»), за якою контейнерні поїзди курсують між терміналами не застосовуючи маневрові операції і переробку на сортувальних станціях;

- розвиток системи регулярних міжнародних перевезень 3 гарантованим терміном поставки вантажів: протягом ночі - на відстань 200-300 км. однієї доби -

750 км і двох діб - 1500 км(Свропа);

більш повне використання потенціалу комбінованих залізничноавтомобільних перевезень контейнерів і контрейлерів (США, Канада), обмінних рефрижераторних кузовів швидкопсувними вантажами (Франція);

- організація перевезень

контейнерів маршрутними поїздами згідно системи «Континентальний міст» 3 пробігом 1500-1600 км на добу, завантаженням контейнерів у два яруси;

- створення комп'ютерних центрів управління перевезеннями з вирішеннями комплексу експлуатаційних задач.

На ці європейські пріоритетні напрямки розвитку залізничної галузі повинна орієнтуватися і наша країна при розробленні відповідних стратегічних напрямків розвитку залізничного транспорту України.

Так на базі розробленої Стратегії розвитку залізничного транспорту України до 2020 р., передбачається реалізація наступних стратегічних напрямків.

технічне переоснащення об'єктів інфраструктури залізниць та забезпечення залізниць рухомим складом вітчизняного виробництва, здатним істотно підвищити техніко-технологічні показники, що дозволить забезпечити прискорення руху потоків вантажів та пасажирів, товароруху, зниження транспортних витрат в економіці i iii ефективне використання по всій вертикалі управління перевезеннями на основі економічних принципів;

удосконалення технології організації перевезень (перехід від принципу «звітних діб» до управління всім процесом, наближене до реального часу), яка

використовує інноваційні технології на основі економічних принципів 3 урахуванням вимог ринку транспортних послуг, економічну оцінку експлуатаційної роботи, включаючи оптимізацію кордонів залізниць;

- впровадження швидкісного руху пасажирських поїздів;

- реформування галузі залізничного транспорту, що передбачає на першому етапі розмежування господарських функцій і функцій державного управління, утворення державного господарського об'єднання на базі Укрзалізниці, залізниць та інших підприємств, установ i організацій залізничного транспорту загального користування, а на другому оптимізацію організаційної структури залізничного транспорту; - удосконалення системи формування тарифів на послуги 
залізничного транспорту та впровадження ринкового механізму ціноутворення у сфері вантажних та пасажирських перевезень;

- створення сприятливих умов для залучення інвестицій 3 метою оновлення та модернізації виробничо-технічної бази залізничного транспорту, забезпечення розвитку державно-приватного партнерства, впровадження механізму лізингу;

- прискорення темпів інтеграції залізничного транспорту до європейської та світової транспортної системи, налагодження тісного міжнародного економічного співробітництва, впровадження принципів європейської транспортної політики, ефективного використання вигідного географічного розташування України для збільшення обсягу транзитних перевезень;

- здійснення комплексу заходів щодо забезпечення безпеки руху поїздів та схоронності вантажів під час перевезень, зменшення негативного впливу залізничного транспорту на навколишнє природне середовище, впровадження ресурсозберігаючих технологій;

- удосконалення

фінансовоекономічної діяльності залізниць, забезпечення їі прозорості;

- підвищення рівня підготовки кадрів та соціального забезпечення - працівників галузі залізничного транспорту, посилення мотивації до праці; підвищення

конкурентоспроможності залізниць на ринках транспортних послуг;

- надання державної підтримки у вирішенні питань щодо закупівлі пасажирського рухомого складу, будівництва і реконструкції об'єктів інфраструктури залізниць, що мають соціальне значення та утримання збиткових залізничних дільниць.

Зараз під впливом інтеграційних процесів, що відбулися у світі та розвиваються у всіх сферах українського суспільства, управління залізничною сферою та стратегія ï розвитку також повинна зазнати суттєвих змін, зорієнтованих на досягнення європейських та світових стандартів.

Тому такі стратегічні напрямки Стратегії розвитку залізничного транспорту України до 2020 р, як «прискорення темпів інтеграції залізничного транспорту до європейської та світової транспортної системи, налагодження тісного міжнародного економічного

півробітництва, впровадження принципів європейської транспортної політики, ефективного використання вигідного географічного розташування України для збільшення обсягу транзитних перевезень» повинні стати найпріоритетнішими.

Висновки. На основі вище викладеного пропонується детальне дослідження даних стратегічних напрямків розвитку інтеграційних процесів в умовах реформування залізничного транспорту 3 виділенням основних складових та відповідних завдань щодо їх реалізації.

Основні стратегічні напрямки розвитку інтеграційних процесів в умовах реформування залізничного транспорту України та їх складові передбачають

$$
\text { - активізацію }
$$

транзитних

перевезень залізничного транспорту

- -позиціювання залізничного транспорту в умовах конкуренції на внутрішньому та зовнішньому ринках;

- напрямки розвитку залізничного транспорту в умовах інтеграції до МТК;

- сучасні підходи до уніфікації перевізного процесу.

- - створення інфраструктури для формування швидкісного руху в Україні

- термінове будівництво швидкісних магістралей, відокремлених від існуючих в Україні залізниць.

\section{ПЕРЕЛІК ВИКОРИСТАНИХ ДЖЕРЕЛ}

1. Дикань В.Л. Островерх Г.Е. Удосконалення механізмів державного 
управління розвитком залізничної галузі України у Свроінтеграційному векторі // Вісник економіки транспорту i промисловості. - 2018. - №62. - С. 11 - 20

2. Позднякова Л.О., Котик В.О. Удосконалення стратегії управління підприємством // Вісник економічного транспорту і промисловості. - 2017. №59. - C. 249 - 256

3. Бараш Ю.С. Савицька Т.М. Методичний підхід щодо розподілення витрат на утримання інфраструктури залізничного транспорту. // Вісник економічного транспорту і промисловості. - 2016. - №54. - С. 224-237

4. Дейнека О.Г, Позднякова Л.О. Теоретичні підходи до державного управління і адміністрування залізничного транспорту. // Журнал Українська залізниця. - 2018. - № 7 (61). - С. 21-25
5. Фриск А « Белая Книга»(Транспорт -2003-№14 (182).- с. 5455

6. Закон України « Про особливості утворення публічного акціонерного товариства залізничного транспорту загального користування» від 23.02.2012p.№4442-VI [Електронний pecypc]- Режим доступу: http: // docvment. ua/proosobivostiutvozennqa-pu

7. Дикань, В.Л. Экономика предприятия [Текст]: учеб. пособие / В.Л. Дикань, Е.В. Шраменко, Н.В. Якименко; Укр. держ. акад. залізнич. трансп. - Х.: УкрДАЗТ, 2008. - 170 с.

8. Іванов, Ю. Б. Теоретичні основи конкурентної стратегії підприємства [Текст] : монографія /Іванов Ю.Б., Тищенко О.М., Назарова Г.В.; Харк. нац. екон. ун-т. - Х. : ІНЖЕК, 2006. - 382 с.

DOI 10.18664/338.47:338.45.v\%vi\%i.145687

УДК 656.2.001.73(477)

\title{
РЕФОРМУВАННЯ УКРЗАЛІЗНИЦІ: СТАН І ОСОБЛИВОСТІ
}

\author{
Слагін Ю.В., к.е.н., доцент, \\ Брильов Д.І., магістр, \\ Зубарєва Л.А., магістр (УкрДУЗТ)
}

\begin{abstract}
Стаття присвячена аналізу поточного стану $i$ особливостей процесу реформування "Укрзалізници", визначенню основних умов $i$ напрямів досягнення ефективних результатів реформування галузі. Розглянуто особливості змін за основними напрямками реформування: організачійної структури управління, технічного оновлення і державного регулювання. Практично зусилля сконцентровані на одному напрямі реформування- зміні організаційної структури ПАТ "Укрзалізниия" і переході до вертикально інтегрованої форми управління. Поточний стан ПАТ "Укрзалізниия" ускладнив роботу по відправленню продукиії металургійної $i$ аграрної галузей економіки Украӥни. Враховуючи теперішній стан функціонування залізничного транспорту України, питання прискорення реформування залізничного комплексу стоїть сьогодні досить гостро. Потрібне удосконалення прочесу закупівель матеріальних ресурсів; прискорене оновлення рухомого складу, в першу чергу тягового; створення умов, механізму і регламентів участі нових учасників в розвитку техніки $i$ технологій, перевезенні і обслуговуванні клієнтів.
\end{abstract}

Ключові слова: державне регулювання, рухомий склад, структура управління, реформування, залізничний комплекс

(C) Єлагін Ю.В.,

Брильов Д.І.,

Вісник економіки транспорту і промисловості № 63, 2018

Зубарєва Л.А. 